
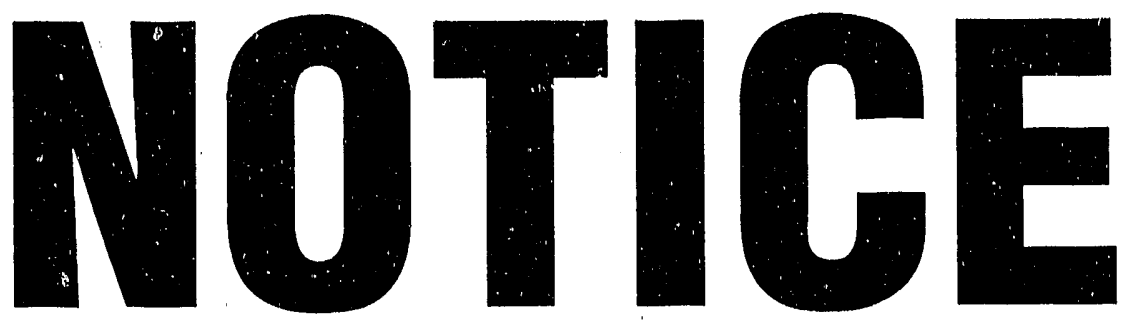

\title{
GERTAN DATA
}
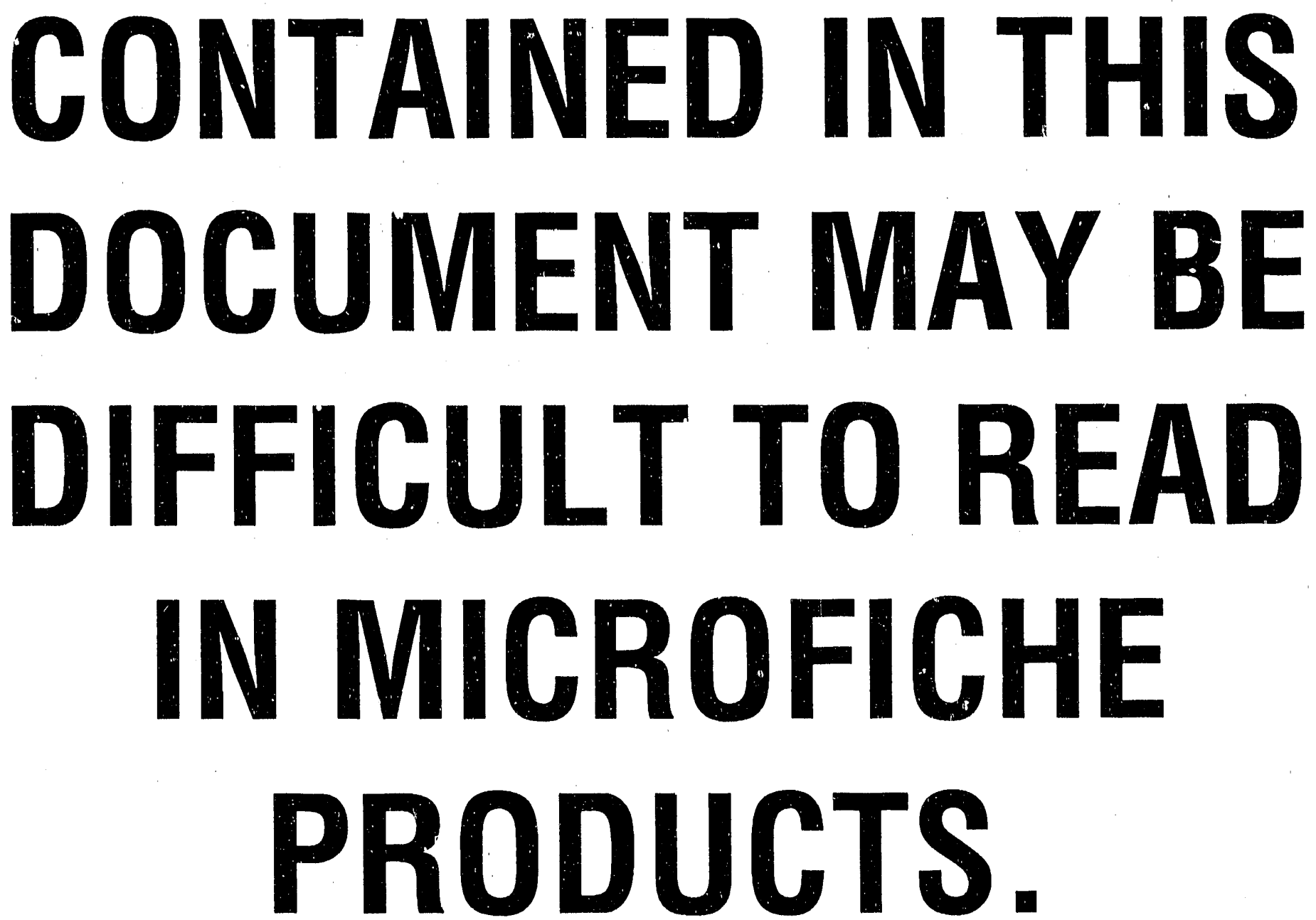
I. GENERAL

Phls ootument conslistwith GENERAL
The D and $T$ Plleg operated at 27511.17 . tiroughout April except for
scheduled outages. Each operat1rus area had an extended outage to remove a portion of the brick from the wall which runs across the rear edge of the top of the unit and to replace the verticnl nooprene seal between the froni frce and the ixperimental side shiolds. This. program is described in detall under incchinical Experfence. The B-P1le was maintained in standby condition with a water flom of $10,150 \mathrm{~g} . \mathrm{p} . \mathrm{m}$. The 100 Aren discharge rato contimed at 60 tons porl? month.

The exclusive use of lead dipped /4" slugg fabricated from alpha rolled or alpha extruded motal was started effective April 1.

Work was started April 12 in the $30 n$ Ares si: a program of decanning 160 tons of $8^{n}$ gamma extrudied triplo-dip canied pieces which were not corisidered good risks for pile operation. The slug recovery operation was placed on a 2 shift per day schedulo or. Ayril 19 to expedite this work so that the metal can be recast and rolled at the earliest moment.

The 300 Area canning production of 90 tons wns governed by the recelpt of rolled rods. At month end a baclilog of sbout 30 tons of rolled rods mas on hand.

\section{ORGAIIZATIOUI AVID FE.SOUIIILL}

In conformance with the general reorganization of the Ceneral Electric Company Nucleonics Program on April 9, the P Depertmont became the $P$ Division of the linmitncturing Diviations:

$$
\begin{array}{lr}
\text { Number of Employecs on Payroll * April } \\
\text { Beglnning of Nonth: } & 295 \\
\text { End of Nonth: } & 308 \\
\text { Not Increase: } & 13
\end{array}
$$

A total of nine clericel porgonnel were transferred on Arril 5 from the Accounting Division to tho P Diviolon as follows:

Due to jilm deterioration, portions of this document may be illegible.

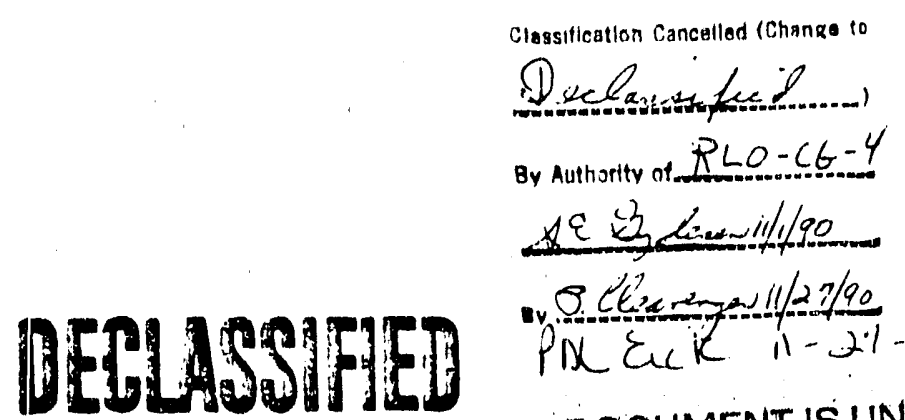

Classificatlon Cancallod (Change to By Authority of $\mathrm{RLO}-\mathrm{CG}^{-4}$ Plí $11-40$ 


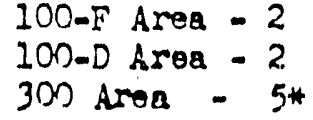

* One male cierk of this group was transferred to the Construction Division on April 19 and was replaced. Two new olertcal personnel were hired for the $300 \mathrm{Ares}$ and are awalting clearance.

One Chlef Operator from 100-D Area was transferred to the 300 Area, and two erperlenced 300 Arse opsrators were transered to the 100 Arens in prenaration for the 100-B Areq startup.

Four new operntors were hilred and assigned to the 300 Area.

H. L. Honry, Assistant Chlef Supervisor, Process Control Group, was transferrod to 100-'] Aroa.

II. E. Barg, Sh1ft Sipervisor, was transferred from 100-D Area to the 300 Area.

R. G. Swift and B. E. Dalton completed their training periods and were 8.391 gned as Shift Suporvisorg to the 300 Area.

\section{AREA ACTIVITIES}

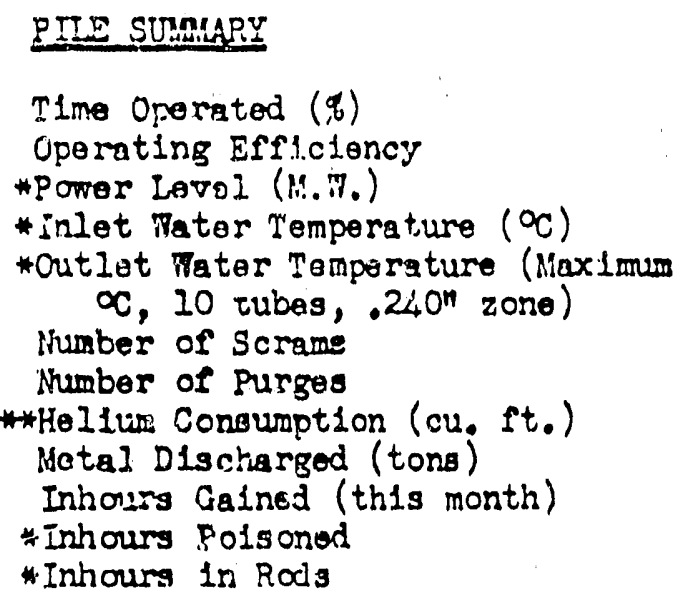

\begin{tabular}{r}
$E[E]$ \\
\hline \\
0 \\
9.3 \\
9.4 \\
0 \\
0 \\
32,406 \\
0 \\
0 \\
-
\end{tabular}

PIE D
74.6
72.8
275
7.4
48.0

$E I E E$
75.8
71.9
275
8.2
54.1

* Nonth end I1guros.

*H1gh helium congumption attributed to purging raquired following noo prene seal replacement nork.

* Twenty-five 1nhours of this attributod to the use of carbon dicoride in the gas clrculating systern.

\section{DISCLAIMER}

This report was prepared as an account of work sponsored by an agency of the United States Government. Neither the United States Government nor any agency thereof, nor any of their employees, makes any warranty, express or implied, or assumes any legal liability or responsibility for the accuracy, completeness, or usefulness of any information, apparatus, product, or process disclosed, or represents that its use would not infringe privately owned rights. Reference herein to any specific commercial product, process, or service by trade name, trademark, manufacturer, or otherwise does not necessarily constitute or imply its endorsement, recommendation, or favoring by the United States Government or any agency thereof. The views and opinions of authors expressed herein do not necessarily state or reflect those of the United States Government or any agency thereof. 
PIIE BUIDING

Outrige Breakdony:

Date of astare

$$
\begin{aligned}
& 4-4-48 * \\
& 4-4-45^{*} \\
& 4-5-48 *
\end{aligned}
$$

$* 1,-i 1-48 * * *$

$4-22-49 *$

$4-17-48$

$4-25-48 * *$

$4-27-48$
Scheduled Votal Discharzed Laintenance

D

D Area shutdown to discharge tomporary foison column

F

D Area shutdom to dischargo temporary pois on columns

$\begin{array}{lrr}F & F & 127.5 \\ D & 19.0\end{array}$

Longth of outage (Hours)

$$
\begin{array}{r}
23.7 \\
23.7 \\
1.4
\end{array}
$$

136.5

23.2

4.0

19.0

*These shutdows were scheduled on consecutive Sundays to allow special tests on the B.P.A. system.

* The length of the allowaole shutdown time in 4-4-48 mas insufficient to complete the work losd; an extended shutdown was required nocessitating a subsequent shutdom on $4-5-48$ as indicatod.

* Bxtimded outage for brlek removal ard saal replacement.

\section{Operating 5xperience}

A mumber of Spectal Request samples were processed during April; detalls of their Irradintian nay be found in the Teathical section of this report.

production Tests having operational siznlfleance during the month are reported below:

105-75-P (Exposure of 4" Slugg)

TTo tiubes of $4^{n}$ slugg were successfully discharged at $250 \%$ of nomal concentration at Area.

105-80-P (Heasurement of Slup Temperatures)

Tube No. 2579-F, contalning a the rmocouplo slug and 16 pleceal of rogular on metal, ras discrargod normalis an April 11 at twice normal concentration.

105-129-P (Effect of Fabrication Temperature on Blistering) A total of 26 tubes containing various combinations of alpha ard gama fabricated metal, both load dippod and triple dipped, ras disoharged on April 4 and II at D Ares with no difficulty. Twonty-six tubes contalning similar

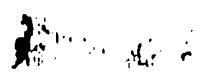




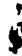

material were discharged at Area on Apr1l 26. Dirf1culty was encountered in dischargling aix of these tubes as detailed under Mechanteal Biperience.

105-168-P (Replaceront of P1lo Hollum Atmosphoro with Carbon D100xide)

The porcentage of carbon dicoxide in the D-P1le atmosphoro was maintainod at 25\% excopt during the extonded shutdown of April 11-16.

105-180-P (Irradiation or an Experimental Beta Slug)

I second experlmental beta typo slug was discharged Hithout iffleulty from the center of dry tube No. 1.81- $\because$ on Apr1 27.

105-180-P, supplenent A (Irradiation of a Beta SIug) Tubo No. LEl-I was replaced oith a new tulo having no frodt $\nabla a n$ stone to allon for expansion. The tube was then charged wh a Bete siug on Apr1l $2 \%$

105-1E3-P (Radiation from Urantum 5ligs)

On April 25, the spesini shielded plus mas removad from the pront end of Tube llo. $1266-F$ and a uranilum slug shielded by a single lead dumny was moved to a position $U_{-}-3 / 4^{n}$ from the front face shleld. A marlarm reading of $5 / \mathrm{mr} / \mathrm{hr}$ was abtalned four inches frem the blolog. al shield. $A$ zaximum heas of $4 \mathrm{mr} / \mathrm{hr}$ (uniorrected) was observed through the lead durams.

Two additional bismuth colums wero chargad at $F$ Area malding a total of 24.

The fllter capacity tests at Bulldings $183-D$ and 183.F mere cantimed during spril.

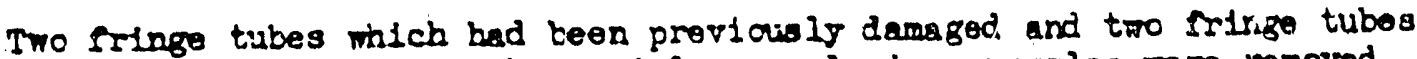
which wore being used with spectal. rear alumimum nozzles were jerovod from sorrlce at F-PLle aning a total of 78 such tubes.

\section{Mechanteal Experience}

All horlzontal and vertical safety rods are in satisfactory operatins condition at wonth ord. Cansiderable mork was done at $F$ Area on vertical rods as follows

Rod guldes re re-allgned an rods $\operatorname{los}, 11,13,14,20,27,31$, and 33. A net tip was Initallod on rod Xo. 30 and the orlginal tip from E. 31 mas rolistalled following berring of the tip and rod gutde.

Sods Nos. 10, 13, 24, 15, 20,21,26, 30, 34, 37, and 38 falled to enter their thisioles by from in to 2 on the Aprll 25 shutdom. 
It wa deterined that the bottam of the thimbles contalned very fine iron dust which could onl be partially removed by a magnot. A program for removal of this material is beling formulated.

At D Area vertical rods Nos. 11 and 16 wore satlsfactorily loosened and all vertical rods were again treated with rust prevontive 011. Tho portodic pnoumatic testing of the rod thimbles was ccopleted.

Horlzcatal rod "A" at $F$ Area was found to have soveml deop scratcines on Apr11 30 a. I it ras given a coat1ng of Aqua-Das. Adjustrent of the hose real tension on 110.5 rod at $F$ Area relleved the binding proviously encountered.

A layer of brick was removed from the wall between the top of the unit and the discharge face at D Area from April $11-16$ and at F Area from April 25-30. This work ma dono to 11 or equal upward expansion of the top shlelds. A canves curtain was installed over the front of the opening to aroid restilation distarbances, and lead brick pas placed behind it to reduce mdiation from the rear faco during discharge operations. Durln the sawe shutdows the front vertical neoprene seals at the experimental side shiold were replaced because of excessive stretching. Conolderable difficuity was experienced at $F$ Area in obtaining a proper flt.

Difrlculty was experienced at $F$ Area in discharging o tibes. Special equipment and extensive oiling were required on lpril 25 to discharge Tubes $100.1072,1156,2785,3403,3570$, and 3.70 , all contalning metal Imar. Iated in accondance with Production Test 105-119-P. Regular metal charges in Tibes fios. 2'131 and 3575 also required spectal equipment for discharging. Forces up to 30.0 pounds per square inch were necessary to move tha charges in Tubes Yos. IISS and 3576. Tube No. 3575 was damaged and it was filled with dumies prior to replacement. Tube 110 . 1165-F and Tube ilo. U3l-F, mich ms used for Production Test 105-180-P, were replaced durtag the April 25 shutdom with tubes of the type intended for DR plle.

The $0.175 n$ ortrices in Tubes No. $1090-F$ and $2190-F$ wore replaced with $0.20 \mathrm{~m}^{\mathrm{N}}$ orifices and Tubes ilos. OS85-F, 20E6-F, and 2259-F wore changed iram 0.200 n to $0.240^{n}$ orfifices on April 25 to relleve high temperature atartup conditions.

Tork was started on the ingtallation of the now sewer line botmeen Bulldings 105 and 107 at $F$ dres. The sewer Iine from Buildings 1.05-B to 107-B was laid bere at three polnts with ane sight crack beling visible. Purther Investigation Fill be made.

The rolds under the floors of the 105-F Butlding were rilled with clay and cement thus completing this rork mhich was brought about by undergrerund water lenks.

Durling routine flushing of the f'ly's eye at 100-B Area, the In plate-glass 
outer len disintegrated with considerable rorce. It appens that the glass was under Internal straln. Plexiglass has been installed in all 100 Areas at this location and the use of this oquipmant has been IImited to exprgency work only.

The chook valves in the $A, B, C$, and $D$ risers at F Area were tested and found to opernte satisfactorili.

A manometer traverse was made on Tube No. 4674-D on Aprtl $U_{4}$ concurrently with tmast surveys of the discharge and experimental faces and the untt top.

\section{Plie Develonment}

Work continued by the Process Control group on the development and eveluation of possible rear face charging michines. E-tensive study by the same group reveals that conslderable helium economies can be reallzed uy modifying certain operating techniques during shutdowns. Essentially, the change which has been adopted as standard involves addition of hellum makeup until the graphite temperature has cooled to equilibriun. Then a small hellum flow is fed directly into the system.

The north retention basin 1 Building 107-D was pumped d.un and the known leaks were treated with $P$ \& $B$ paint thus stopping six of tile nine leaks.

In the south section of the Bullding 107-B basin, which was treated with chlorine in April, it was observed that the algae ure dead but no marood peeling from the walls has ret resulted. Calcium hypachlorite, used in the nort! section of the basin, killed the algae mon wore ragi-liy than did the chiorline and wth smaller quantitios. Further obeervations aro in progress.

\section{GAS PROCESS IIC BUTDTNG}

The firyt car of $99.8 \%$ purity helium was unlanded at Bulliling 110w withcut purification, thereby anving sbout 15,000 cuble foet of hollum.

\section{SPEXIAL HAZA.DOS}

Cont Imed surveys of the experimental side top nooprene $r^{-1}$ Indicated a roading of $29 \mathrm{mr} / \mathrm{hr}$ as compared to $37 \mathrm{mr} / \mathrm{hr}$ in liarch. Flal surveys show the beam to be ribout 30 inches in ridth.

The lead bricks placed on the discharge area slde of the openings cut in the wall across the unit top do not give adequate shlelding and will be roplaced with sheot steel.

300 AREA - MET AL FAERICATION

Praduction Statigtics: 
Production for the month of April was as follows:

$\begin{array}{lr}\text { B1llets Produced } & 63 \text { Tans } \\ \text { Blllets Extruded } & 0 \text { Tons } \\ \text { Rods llachlned } & 131 \text { Tons } \\ \text { Acceptablo Pleces Canned } & 90 \text { Tons }\end{array}$

Melt Plant

The casting glolds wore as follows:

\begin{tabular}{|c|c|c|}
\hline March & Apre1 & $\begin{array}{c}\text { To Dato } \\
1948 \\
\end{array}$ \\
\hline $\begin{array}{l}69 . \\
85 .\end{array}$ & $\begin{array}{l}73.7 \\
89.1\end{array}$ & $\begin{array}{l}71.1 \\
87.5\end{array}$ \\
\hline
\end{tabular}

Billet

Solld lietal

Operation was on a three-shift, fivo-day week schedule throughout the month. The use of solid scrap onle as charge materlal was made standard temporarily to reduce the crucible breakage which results from the use or briquettes. This condition will be relieved furing la" when additional cructbles are rocelved.

On April 1 the iis. 4 coll in tize B rumace began arcing after tro hours and thirteen minites of heating. Tho porer was shut off immediately and the cructble charge ras poured. An inspection of the finsace revealed no reas on for the arcing.

On April 12 the No. 3 coll in A rumace arced. After the furnace was opened for inspection, it was foum that a definite are had occurred across the top of the coll and had burned a small hole in the coll lead. The coll was repalred in position and all cull.3 wore cleaned. The furnace pas operated again on April 13 and tho No. 2 arced on the first run. No apperent reason mas found. After the oolls were cleaned the furnace was operated without further diffeculty.

The power input mas rerluced rrom 112 to $100 \mathrm{imH}$ on April 2. This was done to determine if a lower power input would decrease the carbon c:antent of the billets produced. Difflculty was encountered in pouriris as a result of rhat appeared to be 1ncomplets melting of the crucibio charge. The pouring strean ras slow and fra shaped. The porer input was gradualiy increased unt1l a normal pour was reached. Satisfactory nosults were obtained at $108 \mathrm{KWH}$ and this power input ras mintained for the balance of the month.

Detmation, Outgassing, and liachinting:

Extrus10n, Machining, and Blllet Yields rore as follors: 


\begin{tabular}{|c|c|c|}
\hline \multicolumn{2}{|c|}{$6 \times 1020$} & \multirow{2}{*}{$\begin{array}{l}\text { (s) } \\
\text { To Dato } \\
1948 \\
\end{array}$} \\
\hline 15 & Apr- & \\
\hline $\begin{array}{l}79 . \\
66 . \\
73 .\end{array}$ & 66.5 & 9.3 \\
\hline
\end{tabular}

totrusion

Machining

(Extreudod Rods

(Rolled Pods

\section{B11lots}

The annealing temperature for rolled rods was reduced from 1110 \% $\pm 20^{\circ}$ to 1 ROOF : $20^{\circ}$ on Apri1 $\mathrm{G}$. It Fis found that tine grain structure was satisfactory in the lower range which offered an operational

advantage by controling the tempreatures. weil below the maximum temperature of the alpha range.

Lots 586, 587, and 508, which mere annealed at 1000 \% on Apr 11 14, were found to be under-annealed. Th1s not reported unt1l april 22 and the lots had been processed through canning. The canned pleces have been set aside nnd samples have been taken for metallographic examina. tion to determine if suffictent annealing occurred during canning to gain the desired grain characteristics.

Seventy receptacle slugs $5.00 n \pm 0.10$ n in length, $1.353 n \pm .001 n$ in diameter, and having $21 / 32^{\prime \prime}$ axial holes drilled ihrough them wore machined. They were processed from alpha rolled rods in conformance with Metil Frorlcation Request No. 25.

Four shlpments of rolled rods were recelved in April. Two hundred and eleven rods rere recelved Apri1 7, 116 on April $U_{4}$, and 661 on April 23, fram Joslyr. Steel Company, Fort bayne, Indlans. The fourth shlpment, containing 633 rods, was recelved from Slmonds Sar and 3 teel Company, Lockport, New York, on April 14 .

The machining pleld contimed to be low on rollod rods primarliy as a result of the larger diameter as compared rith extrinded rods. Somo difficulty has been encounteret in mechining rolled rods due to the imegularity of rod dlameters. Solid 3 crap has increased as a result of some sections of rods being very porous and falling to clean up to 4" "An" speciflcations.

\section{Chip Pecove $=$ ard cortde Eurning}

The Ch1p ?ecovery rield was as follows:

\begin{tabular}{|c|c|c|}
\hline Laro & $A D r-1$ & $\begin{array}{l}\text { To Dato } \\
1048 \\
\end{array}$ \\
\hline 90. & 88.9 & 89.4 \\
\hline
\end{tabular}

Chip Recovery operated 15 oighti-hour shifts and processed 37,561 pounds of brlcquottos in April. 
The Ch1p Recovery press was shut dow for repalrg trice during tho wonth. On April 2 1t wis necessnry to resurface the bed plate and replnce the Insert which had cracked. On April 23 the insert cracked again and was roplaced with soster steel facod wh sturite.

The matortal burned in the oxtde burner was as follows:

\begin{tabular}{|c|c|c|}
\hline Maruh & Aprt1 & $\begin{array}{l}\text { To Dato } \\
1948 \\
\end{array}$ \\
\hline 6042 & 6473 & ?o \\
\hline
\end{tabular}

The cxide bumer was operated on a dally schodule.

\section{Caming Operation}

The canning ylold ma as follows:

\begin{tabular}{|c|c|c|}
\hline \multicolumn{3}{|c|}{ a $1101 d \quad\left(4^{n}\right)$} \\
\hline 250 & Apr11 & $\begin{array}{l}\text { To Date } \\
1043 \\
\end{array}$ \\
\hline ?o & 83.6 & 87.1 \\
\hline
\end{tabular}

Canning rejects, by cause, were:

Non-Seating

Marred Surface

Alsi on Outside of can

Frost Test

Bad Tolds

Miscellanoous

\begin{tabular}{|c|c|c|}
\hline 名 & I Cann & $\left(4^{n}\right)$ \\
\hline In & Apr11 & $\begin{array}{l}\text { To Date } \\
1048 \\
\end{array}$ \\
\hline $\begin{array}{r}4.6 \\
1.1 \\
.7 \\
1.2 \\
.8 \\
1.4 \\
\end{array}$ & $\begin{array}{l}9.5 \\
1.0 \\
2.0 \\
1.6 \\
1.3 \\
1.0 \\
\end{array}$ & $\begin{array}{l}5.2 \\
1.2 \\
1.5 \\
1.6 \\
1.3 \\
2.1\end{array}$ \\
\hline 9. & 16.4 & 12.9 \\
\hline
\end{tabular}

The difflculty from non-seating, discussed last month, was encountered again throughout this period. A Brown recorder was substituted for the lifer in the AIS1 thermal ansiysis apparatus in an offort to improve repreduclbility of results. The trials in which the Brown was used were unsatisfactory and the instrument is now belng remodeled to improve sensitivity. Chromel-Alumel lead wirn has been received and plans aro being made to replace all rumace thermocouplo lead wires as soon as posstble. It has been observed that a number of rolled slugs having very small longltudinal surface cracks have a frosty appearance after boing prehented in the $\mathrm{Pb}$ bath. This also has contributed to non-seating. A study of the posolblo causes for this condition is currentls bolng mado. 
Work was resumed on the recovery phase of Production Test No. 313-94-4, "Development of Lead Dip Process" on April 13. The purpose of this phase of the test is to develop a process for recovering canned rejects by the land dip process to supplement the standand chemlcal recovery process. Results thus far indicate that recovery can be accosplished by plereing a hole through the bage of the aluminum oan, preheating the reject in the load bath for thirty seconds, then remooling from the bath and using special tongs for removing the can from the slug. The slug can then bo agitated in the Al31 layer on the lead bath for three seconds, transforred to the AlS1 canning bath, agitated in the bath for three seconds, and rocanned in the remular manner.

One plece exch of Special Request 77 and 78 (radium chlorlde) mere succossfully canned after the mushroomed bottoms on the pleces had been spun down to the correct dlameter. Seventeen pleces of Special Request No. 53 (Uranilu enriched $\pi 1$ th U235) wero canned. Four pleces falled to pass the bubble test before canning and w1I he returnod to the vendor.

A total of 2,211 polson slugs was canned during the month. Reconery Cperation:

\begin{tabular}{|c|c|c|c|}
\hline \multicolumn{2}{|c|}{ \& Recorered } & \multicolumn{2}{|c|}{ Avergge $M t, ~-~ I b s}$. \\
\hline Apr11 & $\begin{array}{l}\text { To Date } \\
1048 \\
\end{array}$ & Apr11 & $\begin{array}{l}\text { To Dato } \\
1948 \\
\end{array}$ \\
\hline $\begin{array}{l}66.9 \\
22.0 \\
11.1\end{array}$ & $\begin{array}{r}74.0 \\
17.9 \\
8.9 \\
\end{array}$ & $\begin{array}{r}3.912 \\
3.851 \\
\end{array}$ & $\begin{array}{r}3.909 \\
3.853 \\
\end{array}$ \\
\hline 100.0 & 100.0 & & \\
\hline
\end{tabular}

\begin{tabular}{|c|c|c|c|}
\hline $\begin{array}{l}\text { Z Slugs } \\
X \text { Slugs } \\
\text { Rojects }\end{array}$ & $\begin{array}{r}66.9 \\
22.0 \\
11.1 \\
\end{array}$ & $\begin{array}{r}74.0 \\
17.9 \\
8.1 \\
\end{array}$ & $\begin{array}{r}3.912 \\
3.851 \\
-\end{array}$ \\
\hline & 100.0 & 100.0 & \\
\hline
\end{tabular}

The recovery of all gamme extruded $8^{n}$ triple dip canned pleces ( 160 tons) was started on April 12. These pleces are belng converted to solld scrap for remelting. On Anril 19 the oneration was placed on a two shift per dag basis.

Inspection and Testing

Autoclave rejects as follom:

$\frac{\text { Minrch }}{0.49 / 11} \quad \frac{\text { Aprt] }}{0.51 / 19} \frac{\begin{array}{l}\text { To Dato } \\ 1048\end{array}}{0.47 / 4}$

Twenty autoclave tallures occurred during the nonth; stx of these were ccomplotels destroored.

The "As Rocelrod" quallty of cans, chps, and slooves inspected during the month was 28 rollows:

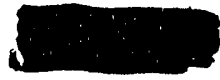



C3, KS, and KC ippes of graphite and single bar tests an all "rinished" graphito. In addition, the mumber of sample bars from each heat bas been reduced from tronty-two to sixtoen. Based on the abore it nom appears that the present operatling schedule for the test unit w111 bo adequate to cover all tests scheduled in the coolng months.

The olassification of graphite bars was changed from the $E, D, H, M$, and $P$ olasses to the following on April 17:

Grade

$S$ in Range

Fled

lass than 0.08

Bluo

+0.08 to 0.20

insto

Green +0.20 and abovs ( 0.20 to 0.60 for "Flulabed"
only)

Attor testing, all samplo bars are stamped conforming with the above $\Delta$ ih ranges and in accordance with the sollowing tablo to facilitate the handling at the 101 Bullding.

Type of

Graphite

GS

KS

IC

\section{+0.60
plo bers
co with}

\begin{tabular}{llcl}
\multicolumn{4}{c}{ Grade of Graphite } \\
\hline Red & BIide & Thite & Groen \\
$R-1$ & $B-1$ & $\pi-2$ & $G-1$ \\
$R-2$ & $B-2$ & $\pi-2$ & $G=2$ \\
$R-3$ & $B-3$ & $\pi-3$ & $G-3$
\end{tabular}

Note:

AII "plaishod" graphito falling 1nto tho whito grade 1.8 identifled by if plus the mumber.

\section{Devolopment For?}

On April 9 a test was made to determine the value of helfum a cooling medium to reduce the molt furnace cooling cycle. The furnace temperaturo was reduced to $785^{\circ} \mathrm{C}$ in one hour and forty intmites, On April 19 B rorrace was purged with 535 cublc foot of hollum firteon minutes after pourlas the final chargo. In ono hour and ton olmutes the rarnace was coolod to $780^{\circ}$. The norral tire requitred to $c 001$ the nimaces to $800^{\circ} \mathrm{C}$ without. hollum is approximatels two hours and s1fteen rimutes. It 1s ovident that the coollag eycle can be decreased appreciably through the use of heilum but 1ts use does not appear to be oconomical at the prosent t,1me.

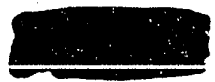




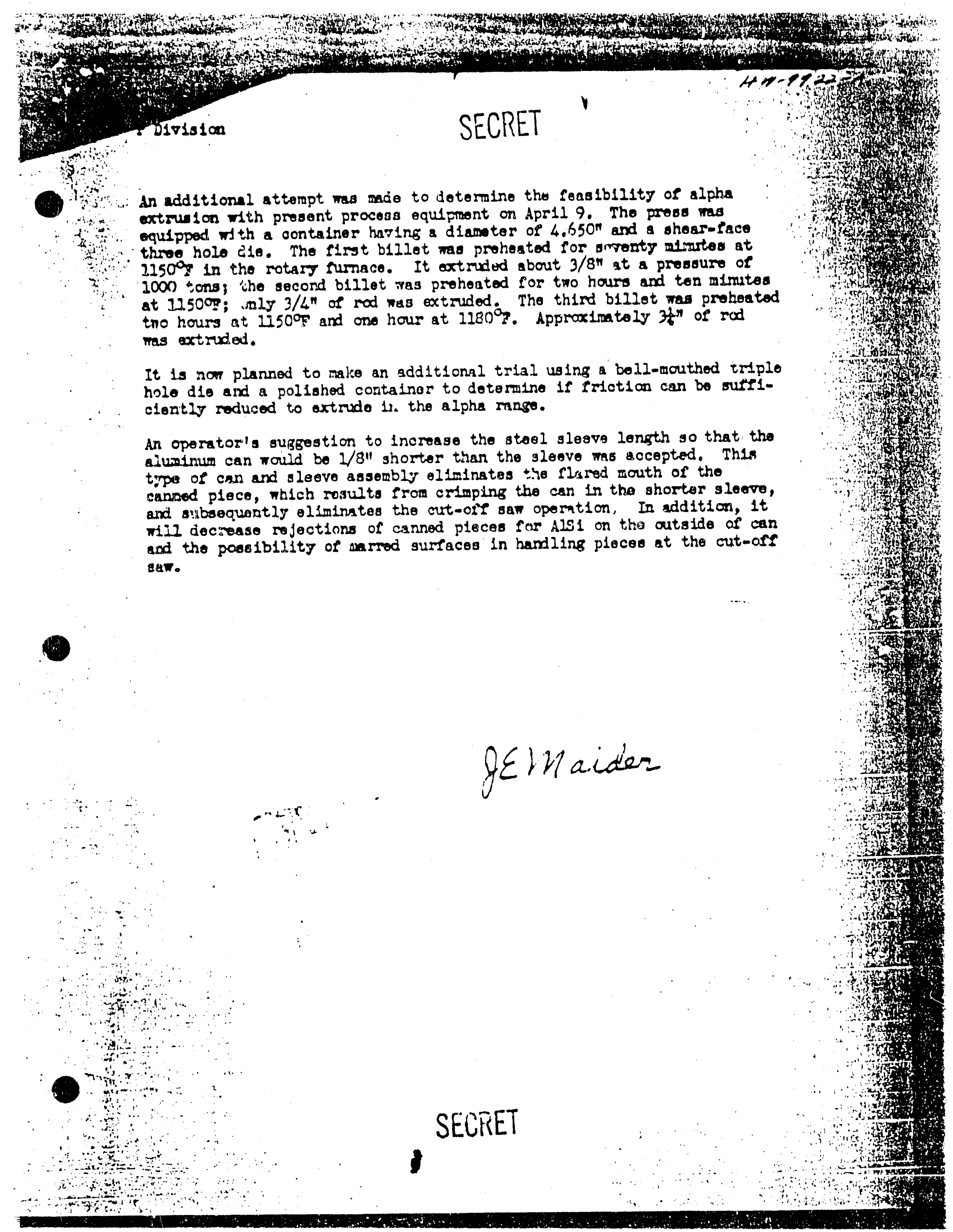



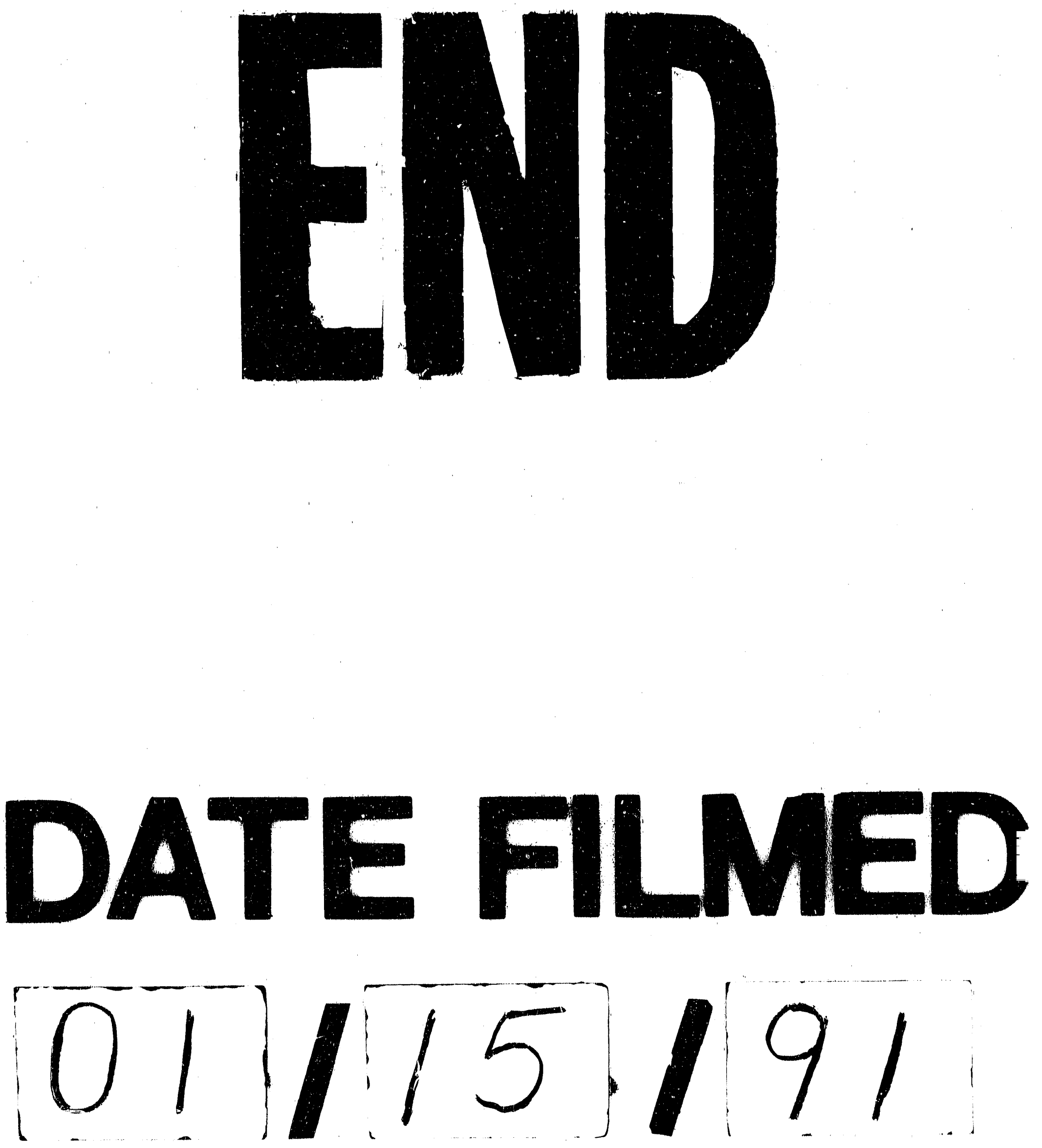
